\title{
(-) astax \\ Epstein-Barr virus associated with high-grade B-cell lymphoma in nude severe combined immunodeficiency
}

\author{
Rawia Albar, ${ }^{1,2}$ Moaffaq Mahdi, ${ }^{1}$ Fawaz Alkeraithe, ${ }^{1}$ Khalid Nawaf Almufarriji ${ }^{1}$
}

${ }^{1}$ King Saud bin Abdulaziz University for Health Sciences College of Medicine, Jeddah, Saudi Arabia

${ }^{2}$ Pediatric Department, King Abdulaziz Medical City, Jeddah, Saudi Arabia

\section{Correspondence to} Mr Moaffaq Mahdi, moaffaq.mahdi@gmail.com

RA and MM are joint first authors.

Accepted 15 May 2019

Check for updates

(c) BMJ Publishing Group Limited 2019. Re-use permitted under CC BY-NC. No commercial re-use. See rights and permissions. Published by BMJ.

To cite: Albar R, Mahdi $\mathrm{M}_{\text {, }}$ Alkeraithe $F$, et al. BMJ Case Rep 2019;12:e227715. doi:10.1136/bcr-2018227715

\section{SUMMARY}

Severe combined immunodeficiency (SCID) is an extremely rare disease caused by a disruption in the forkhead box N1 (FOXN1) gene, with an incidence of $<1$ per 1000000 live births. We report a boy aged 4 months who presented with a history of fever for 3 weeks and enlarged lymph nodes. The fever was associated with dry cough and runny nose. On physical examination, we noted oral thrush, generalised lymphadenopathy, nail dystrophy and alopecia. Flow cytometry of lymph node biopsy showed high-grade B-cell lymphoma. In addition, Epstein-Barr virus (EBV) infection was documented by PCR. The diagnosis of SCID was made by genetic testing, which revealed a homozygous variant of the FOXN1 gene. The variant was confirmed with Sanger sequencing. Management of EBV infection and lymphoma was initiated; unfortunately, the patient passed away on day 45 of hospitalisation.

\section{BACKGROUND}

Forkhead box N1 (FOXN1) gene mutation disrupts epithelial maturation in the skin, hair, nails and thymus. This disruption leads to impaired T-cell maturation. Consequently, it is characterised by a clinical triad of T-cell deficiency, nail dystrophy and alopecia. ${ }^{1}$ FOXN1 gene mutation is an extremely rare cause of severe combined immunodeficiency (SCID), with an incidence of $<1$ per 1000000 live births. In patients with SCID, severe infection is the most common presenting symptom, and can be life-threatening in some cases. Only 10 cases have been reported to date. ${ }^{23}$ The first case was reported in 1996 in two Italian sisters born to non-consanguineous parents. ${ }^{4}$ This is the first case of FOXN1 deficiency to be reported in the Arabian Gulf region. Furthermore, to the best of our knowledge, this is the first case of FOXN1-deficient SCID presenting with high-grade B-cell lymphoma.

\section{CASE PRESENTATION}

A boy aged 4 months was born at full-term by caesarean section with no postnatal complications to a first-degree consanguineous couple. The baby received the BCG vaccine at birth without developing any complications and developed no scar abscess. He was in a normal state of health until he was 4 months old, when his mother brought him to the emergency department with a complaint of fever and neck swelling for 3 weeks. At presentation, he had a fever of $38.5^{\circ} \mathrm{C}$ that had not subsided after a completed course of amoxicillin. The fever was associated with dry cough, runny nose, oral thrush and generalised lymphadenopathy. In addition, he had alopecia, thymic aplasia and dystrophic nails in all upper and lower limbs. There was a $2 \times 2 \mathrm{~cm}$ well-demarcated circular erythematous area on the left medial aspect of the knee. He was given packed red blood cell transfusions twice.

The child had a family history of sibling death at 7 months of age due to a brain anomaly. While at the hospital, the patient's fever spiked to $39.5^{\circ} \mathrm{C}$, and he started desaturating (blood oxygen saturation, $\mathrm{SpO}_{2}=82 \%-96 \%$ ) with signs of respiratory distress such as nasal flaring, grunting and subcostal retraction. On auscultation, there were transmitted sounds with no wheeze or crepitations. He was treated empirically for bacterial sepsis and oral Candida. Subsequently, his symptoms improved and he was put on a nasal canula.

\section{INVESTIGATIONS}

Laboratory workup showed that his lymphocyte level was $0.38 \times 10^{9} / \mathrm{L} \quad\left(1.50-4.00 \times 10^{9} / \mathrm{L}\right)$. Flow cytometry of the lymphocyte subset showed CD3 + (T-cell), 10\%/L (58\%-67\%); CD3+CD4+ (T-helper), $\quad 1 \% / \mathrm{L} \quad(38 \%-50 \%) ; \quad \mathrm{CD} 3+\mathrm{CD} 8+$ (T-supp), 2\%/L (18\%-25\%); CD19+ (B-cell), 3\%/L (19\%-31\%); CD16 + CD56+ (natural killer (NK)), 87\%/L (8\%-17\%); T-cells, 45.0 cells/ $\mu \mathrm{L}$; T-helper, 4.0 cells $/ \mu \mathrm{L}$; T-supp, 9.0 cells $/ \mu \mathrm{L} ;$ B-cells, 14.0 cells/ $\mu \mathrm{L}$; NK, 392.0 cells/ $\mu \mathrm{L}$; lymph, $18 \% \mathrm{~L}$; CD4/ CD8 ratio, $0.50 \mathrm{~L}$ (1.50-2.90 L); white blood cells, $2.50 \times 10^{9} / \mathrm{L} ; \mathrm{CD} 3+\mathrm{CD} 45 \mathrm{RA}, 1 \%$; CD $3+\mathrm{CD} 45 \mathrm{R} 0$, 96\%; CD3 + T-cell receptor (TCR) $\alpha / \beta, 10 \%$; CD3 + TCR $\gamma / \delta, 90 \%$; CD $3+$ CD $4+C D 8-$ T-cells (double-negative T-cells), 83\%.

In addition, bone marrow biopsy showed signs of infiltration, with 5\% abnormal mature B-cells on flow cytometry.

Chest X-ray showed significant bilateral peribronchial thickening and cardiomegaly. Respiratory culture demonstrated heavy growth of Pseudomonas aeruginosa. In addition, Epstein-Barr virus (EBV) infection was documented by PCR (339 095 IU/ $\mathrm{mL}$ ). Therefore, he was started on ganciclovir twice a day $(10 \mathrm{mg} / \mathrm{kg} /$ day, divided). CT scan of the neck, chest, abdomen and pelvis showed diffuse enlargement of the cervical, bilateral axillary, mesenteric 


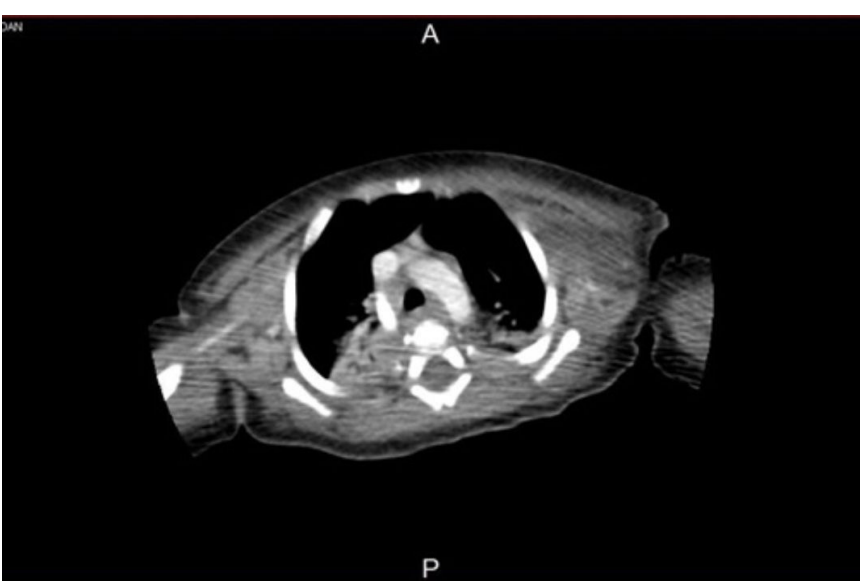

Figure 1 Chest CT scan of a boy aged 4 months showing absence of thymus tissue (congenital thymic aplasia).

and bilateral inguinal lymph nodes. In addition, thymic aplasia was noted (figure 1).

Axillary lymph node biopsy showed high-grade B-cell lymphoma, focally CD30+, with plasmacytoid differentiation. Epstein-Barr encoding region (EBER) staining was warranted to differentiate between an EBV-driven lymphoproliferation and lymphoma. The EBER staining was negative for EBV-driven lymphoproliferative disorder (figure 2). Histological examination showed diffuse effacement of architecture with sheets of lymphoid cells having moderate cytoplasm and vesicular nuclei with nucleoli. Mitosis is evident. Apoptotic debris noted. Flow cytometry of the lymph node biopsy showed that the majority of cells were B-cells expressing CD19, CD20, CD38 and human leucocyte antigen (HLA)-DR with surface immunoglobulin. There was lambda light chain restriction. Moreover, there was a small population of mature T-cells expressing CD2, CD3, CD5 and CD7, but which were mostly negative for CD4 and CD8. The majority of T-cells were positive for $\gamma / \delta(85 \%)$ and $\alpha / \beta(15 \%)$ receptors. We suspected X linked lymphoproliferative (XLP) syndrome. Therefore, genetic testing was warranted, and whole-exome sequencing was performed for the patient and parents. The results demonstrated a homozygous variant of the FOXN1 gene (R320W), c.1579_1580del p,(Thr527); Chr17

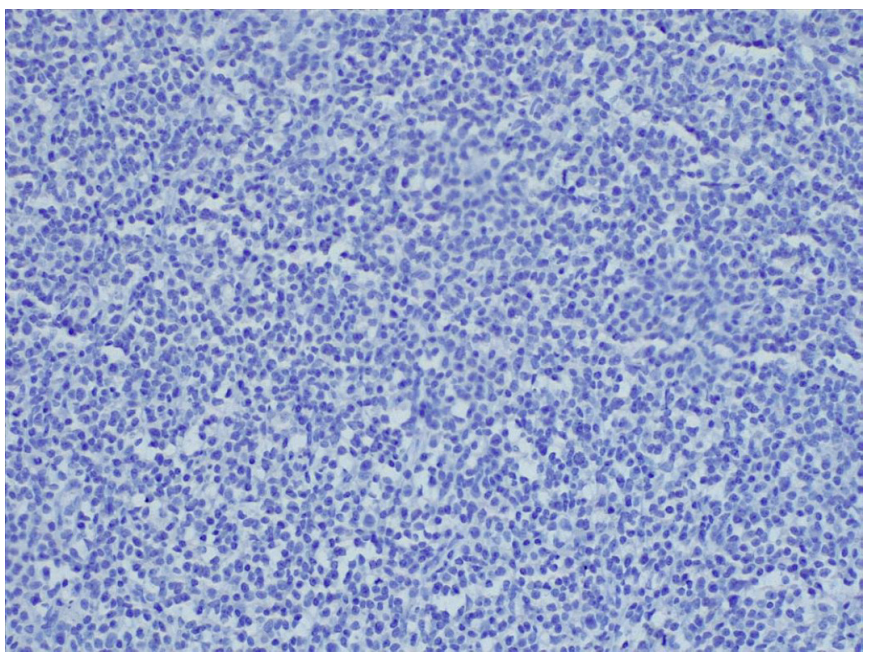

Figure 2 Axillary lymph node biopsy with negative EpsteinBarr encoding region staining for Epstein-Barr virus-driven lymphoproliferative disorder.
(GRCh37). The variant was confirmed by Sanger sequencing. Furthermore, it was detected in both parents in a heterozygous state. It was classified as likely pathogenic class 2 . Therefore, a diagnosis of SCID from FOXN1 gene mutation was made. During the 45 days in the hospital, the patient was transfused with cytomegalovirus-negative red blood cells 11 times, one unit at a time. In addition, platelets were transfused 17 times in a total of 26 units, as well as one unit of cryoprecipitate and one unit of fresh frozen plasma.

\section{DIFFERENTIAL DIAGNOSIS}

- XLP syndrome.

- Omenn syndrome.

- EBV-driven lymphoproliferative disorder.

\section{TREATMENT}

Intravenous methylprednisolone, $10 \mathrm{mg}$ once daily (MBC09 protocol), changed to cyclophosphamide, vincristine and prednisone chemotherapy for B-cell lymphoma.

\section{OUTCOME AND FOLLOW-UP}

The patient passed away on day 45 of hospitalisation.

\section{DISCUSSION}

Here, we report a case of an infant aged 4 months presenting with thrombocytopenia, EBV infection, lymphadenopathy and oral thrush with clinical features of FOXN1 deficiency. SCID was diagnosed by genetic testing, which revealed a homozygous variant of the FOXN1 gene, confirmed by Sanger sequencing confirmed. In addition, flow cytometry of lymph node biopsy showed high-grade B-cell lymphoma. EBV infection was documented by PCR. Management of EBV infection and B-cell lymphoma was initiated, but the patient passed away on day 45 of admission.

Only three mutations have been discovered to date in the human FOXN1 gene: R255X, R320W and S188fs. In all R255X homozygous mutation cases, there was a significant number of non-maternal origin T-cells circulating in the body. In contrast, R320W mutations show no T-cells circulating in the patient. ${ }^{4-7}$ Here, we encountered a new mutation that differed from the 10 previously reported cases. The new mutation is T527X, a premature stop codon. It results from a deletion in exon 6, c.1579_1580del. Similar to the R320W mutation, T527X shows no circulating T-cells in the patient.

To our knowledge, none of the reported cases of FOXN1-deficient SCID had associated lymphoma. In contrast, this is the first case that presented with associated high-grade B-cell lymphoma. We hypothesise that EBV infection might have contributed to the development of the B-cell lymphoma (ie, EBV-associated lymphoma). Furthermore, the lymphoma infiltrated the bone marrow, which can explain the patient's thrombocytopenia.

Live attenuated vaccines such as the BCG vaccine are contraindicated in patients with SCID. A 2014 study that collected data from 349 patients with SCID who had received BCG vaccines found that $51 \%$ of the patients developed localised and disseminated complications. ${ }^{7}$ In the present case, our patient had received the BCG vaccine, but had not developed complications, and there was no development of BCG scar abscess.

Central nervous system (CNS) abnormalities were observed in some cases without being attributed to FOXN1 deficiency. One report described two fetuses with homozygous FOXN1 deficiency who had multiple neural tube defects in the form of spina bifida and anencephaly. ${ }^{8}$ However, it is remains unknown 
whether CNS involvement is a standard feature of this mutation. Our patient did not have CNS abnormalities. However, he had a sibling who had died at a young age due to a brain anomaly. Considering the presence of consanguinity and lack of information, the sibling's brain anomaly might have been caused by FOXN1 deficiency or other gene mutations.

Thymus transplant and haematopoietic stem cell transplantation (HSCT) offer promising results for patients with SCID. Two cases were described to have undergone thymus transplantation, and the authors concluded that it had normalised T-cell proliferative response and improved clearance of disseminated infections in the patients. ${ }^{5910}$ Three cases had been treated with HLA-matched HSCT. One patient was free from infection 6 years after transplantation and showed immune reconstitution. Another recipient died from postoperative complications. ${ }^{10}$ Due to the aggressive presentation in the present case, the patient did not have the chance to undergo thymus transplant.

In conclusion, although SCID is extremely rare, early detection and management can decrease the mortality rate at an early age. ${ }^{5}$ FOXN1 deficiency should be considered one of the differential diagnoses in patients presenting with a clinical triad of T-cell deficiency, nail dystrophy and alopecia.

\section{Learning points}

- Patients with severe combined immunodeficiency (SCID) can present with large B-cell lymphoma.

- A history of central nervous system abnormalities is associated with SCID and should be queried in the history-taking.

- Early diagnosis of the disease, followed by thymus transplantation, can yield promising results.

Acknowledgements The authors would like to acknowledge :-Dr Albaraa Attieh Alghamdi for collecting resources. Mr Taher Khalid Felemban and Mr Bassel Abdulaziz Almehman for review the article. Mr Mohammed Yasser Tashkandi for a genetic interpretation.

Contributors RA was the most responsible physician on the patient case. RA and MM are the first authors who founded the research team. Also, the first authors contacted the patient family to sign the consent. FA and KNA were interested in the case. KNA did a literature review for the diagnosis of severe combined immunodeficiency. Furthermore, all authors reviewed the patient file, identified and discussed the rarity and the main topics related to the subject. Moreover, all authors contributed to writing the final manuscript. MM wrote the background for the article and apply for the BMJ. FA, collected and wrote the history and the investigations. FA wrote the case discussion. Last but not least, the case report was supervised by RA, throughout the whole process.

Funding The authors have not declared a specific grant for this research from any funding agency in the public, commercial or not-for-profit sectors.

Competing interests None declared.

Patient consent for publication Parental or guardian consent obtained.

Provenance and peer review Not commissioned; externally peer reviewed.

Open access This is an open access article distributed in accordance with the Creative Commons Attribution Non Commercial (CC BY-NC 4.0) license, which permits others to distribute, remix, adapt, build upon this work non-commercially, and license their derivative works on different terms, provided the original work is properly cited and the use is non-commercial. See: http://creativecommons.org/ licenses/by-nc/4.0/

\section{REFERENCES}

1 Frank J, Pignata C, Panteleyev AA, et al. Exposing the human nude phenotype. Nature 1999:398:473-

2 Rota IA, Dhalla F. FOXN1 deficient nude severe combined immunodeficiency. Orphanet J Rare Dis 2017;12:6

3 Radha Rama Devi A, Panday NN, Naushad SM. FOXN1 Italian founder mutation in Indian family: Implications in prenatal diagnosis. Gene 2017;627:222-5.

4 Pignata C, Fiore M, Guzzetta V, et al. Congenital Alopecia and nail dystrophy associated with severe functional T-cell immunodeficiency in two sibs. Am J Med Genet 1996;65:167-70.

5 Markert ML, Marques JG, Neven B, et al. First use of thymus transplantation therapy for FOXN1 deficiency (nude/SCID): a report of 2 cases. Blood 2011;117:688-96.

6 Chou J, Massaad MJ, Wakim RH, et al. A novel mutation in FOXN1 resulting in SCID: a case report and literature review. Clin Immunol 2014;155:30-2.

7 Marciano BE, Huang CY, Joshi G, et al. BCG vaccination in patients with severe combined immunodeficiency: complications, risks, and vaccination policies. J Allergy Clin Immunol 2014;133:1134-41.

8 Amorosi S, D'Armiento M, Calcagno G, et al. FOXN1 homozygous mutation associated with anencephaly and severe neural tube defect in human athymic Nude/ SCID fetus. Clin Genet 2008;73:380-4.

9 Albuquerque AS, Marques JG, Silva SL, et al. Human FOXN1-deficiency is associated with $\alpha \beta$ double-negative and FoxP3 + T-cell expansions that are distinctly modulated upon thymic transplantation. PLoS One 2012;7:e37042.

10 Gallo V, Cirillo E, Giardino G, et al. FOXN1 Deficiency: from the Discovery to Novel Therapeutic Approaches. J Clin Immunol 2017;37:751-8.

Copyright 2019 BMJ Publishing Group. All rights reserved. For permission to reuse any of this content visit

https://www.bmj.com/company/products-services/rights-and-licensing/permissions/

BMJ Case Report Fellows may re-use this article for personal use and teaching without any further permission.

Become a Fellow of BMJ Case Reports today and you can:

- Submit as many cases as you like

- Enjoy fast sympathetic peer review and rapid publication of accepted articles

- Access all the published articles

- Re-use any of the published material for personal use and teaching without further permission

Customer Service

If you have any further queries about your subscription, please contact our customer services team on +44 (0) 2071111105 or via email at support@bmj.com.

Visit casereports.bmj.com for more articles like this and to become a Fellow 